ESJ Social Sciences

\title{
Sandwich Model of Educational Upgrading in Ghana: A Transitional Challenge in Disguise
}

\author{
David Nii-Okai \\ Ebenezer Acheampong \\ Inuusah Mahama \\ Jonathan Kwame Mensah \\ Osman Imoro \\ University of Cape Coast, Ghana \\ Richard Marfo \\ Agogo College of Education, Ghana \\ Regine Kwaw \\ Enchi College of Education, Ghana \\ Seth Odame-Mensah \\ University of Cape Coast, Ghana
}

Doi:10.19044/esj.2021.v17n8p136

Submitted: 02 November 2020

Accepted: 23 March 2021

Published: 31 March 2021
Copyright 2021 Author(s)

Under Creative Commons BY-NC-ND

4.0 OPEN ACCESS

Cite As:

Nii-Okai, D., Acheampong, E., Mahama, I., Mensah, KJ., Imoro, O., Marfo, R., Kwaw, R., and Odame-Mensah, S. (2021). Sandwich Model of Educational Upgrading in Ghana: A Transitional Challenge in Disguise. European Scientific Journal, ESJ, 17(8), 136. https://doi.org/10.19044/esj.2021.v17n8p136

\section{Abstract}

The study investigated transitional challenges among undergraduate (bachelor of education) sandwich students. Adopting the descriptive survey design, a census population of 651 was used. Sanagavarapu, Abraham and Taylor's (2018) TWHAS was used for data collection. The data was 
analysed using frequency counts and MANOVA. The study revealed that $59.6 \%$ of the students experienced difficulty in balancing family commitments with studies, $77.4 \%$ found it difficult to exercise, $61.0 \%$ found it difficult meeting up with friends and $73.3 \%$ found it difficult balancing financial commitments. Again, $45.2 \%$ of the students rarely experienced misunderstanding, while $25.0 \%$ were concerned about what others would say about them, 29.2\% were concerned about the language barrier, $75.7 \%$ were concerned about their inability to explain their problems but $81.9 \%$ were not afraid seeking support from colleagues. More so, females experienced transitional challenges more than males. It is recommended for managers of the programmes to counsel students so as to control the effects of the challenges.

Keywords: Transition, Challenge, Undergraduate, Sandwich Students, Academic Programmes

\section{Introduction}

Educational upgrading (higher education) has become common among many professionals including teachers. Teachers, as they embark on their higher education journey, have to defy all odds and transit from their 'comfort zones' to institutions where tuition can be received. According to Allard and Perry (2003), transition in education refers to an internal course in the mind, which occurs while students experience a change from a routine to the inexperienced; responding to the cultural, social and individual's difficulties in the behaviour. This act of teachers moving from one place (homes or comfort zones) to another (new school environment) has nothing ordinary to offer them but transitional issues in their quest for knowledge acquisition. On the basis of this, Parker et al. (2017) note that several academic and non-academic difficulties exist for students, of which they must overcome when moving from one place to another to further their education. Despite the interesting moments attached to the new entrant in the new educational journey, it is important to note that the period could be challenging for students in terms of general adaptation (Parker et al., 2017). According to Wangeri, Kimani and Mutweleli (2012), university entry globally offers students with opportunities in diverse ways to define and advance their professional prospects. Due to different socioeconomic backgrounds of students, the university's physical and social settings may look new, devastating and threatening to some students. Consequently, many students starting universities possess mysterious fears and expectations about life and education in the university. While some students rejoice over gaining admission to the university, the admission also brings about extreme apprehensions since some students are distant breaking from regular places 
and people in their lives for the first time. Bling (as cited in Wangeri, Kimani \& Mutweleli, 2012) opined that transition in any educational level is recognized as a shaker of social security, physical comfort and ability to enjoy satisfying activities for new entrants. Bernier, Larose, and Whipple (2005) affirmed this assertion that educational transition can be a worrying social and mental event. This is because autonomy away from parents and known people are to be tested as first year students are required to make decisions concerning day-to-day activities personally. Corroboratively, Talbert (as cited in Wangeri, Kimani \& Mutweleli, 2012) notes that each first-year student is required to make decisions about when and what to do as well as when to sleep and wake up. Before the new life in the university, important figures such as parents, friends, neighbours and teachers guide potential university students about the 'pros' and 'cons' of university life. Such guidance extends to the kind of friends a potential university student keeps. In this regard, students are prompted of where to be at what time using a customary reminder of what to do and where to be.

Noting this, Jeyagowri and Ilankumaran (2018) assert that an effective transition takes a longer time for students to cope with. Hence, a progressive and fruitful transition in education is fundamental if students are to remain in the course in higher education and experience prosperous consequences (Parker et al., 2017). Tinto (2013) in a study emphasized that the influences students receive preceding their university courses define how prepared they become for social and academic integration into tertiary education. According to Tinto, such influences compel students to set expectations concerning what the university has for them and likelihood response on the part of the students. Hughes (2016) submits that several students are faced with unclear or impractical expectations of university. In studies such as Kahneman (2012) and Tinto (2013), many new university students endorsed the assertion that students have trouble in envisaging the future with impracticable beliefs. In this case, assisting students in terms of setting reasonable expectations and beliefs about the university would help in their transitional experiences. Harvey, Drew and Smith (2006) in a study asserted that the most important component of expectations students held is not about accuracy but how flexible and appropriate such expectations could be. Therefore, assisting students to broaden their expectations and recognize differences in expectations could be more productive than attempting to challenge and change the current beliefs of students (Harvey et 1., 2006).

Noting the setbacks in transiting from one community to another, students arrive at university without the required personal, social and academic skills for a successful integration into the university (Norton, Keenan, Williams, Elander, \& McDonough, 2009). Oliver and Kettley (2010) indicated that problems of time management, flexibility, managing 
relationships and budgeting persistently become eminent among transiting students. These problems, according to Oliver and Kettley (2010), are not solely caused by the transitional process but because most universities are examination-focused than knowledge acquisition, hence students experience problems as they join the university. According to Zajonc (2001), this is challenging, not because beginning students are expected to be responsible for their own learning but because superficial learning is likely to cause higher levels of anxiety and reduce students' academic attainment greatly in the university. Ameliorating these challenges is possible through acquisition of pre-university skills among students transiting and a change in their learning approach could be beneficial in this regard (Walker, 2010).

Taking demographic characteristics into perspective, Sangeeta and Chirag (2012) in a study revealed that transiting university students with poor socio-economic background and poor academic achievement experience more transitional problems than their counterparts with high socio-economic backgrounds. Gender wise, Surekha (2008) in a study found that female transiting students experience more transitional problems than their male colleagues. In a related study with the aim of establishing differences in transitional problems among transiting university students, it was revealed that the mean score for the males and that of females was the same (Mean=40.0), hence, the conclusion that no differences existed between them as they transit to the university as first years. Therefore, gender could not contribute to any challenge transiting students experienced in the university in the study (Muntazir \& Kermane, 2015). Research works by Enochs and Ronald (2006) and Abdallah, Elias, Muhyddin, and Uli (2009) revealed significant differences in gender of transiting university students in terms of the challenges they face in the transitional process, where male students experienced less transitional challenges than female students. A similar study was conducted by Edjah, Domey, and Ankomah (2019) concerning transitional challenges students experience, using first year university students in Ghana. Comparing male and female students using the independent samples t-test, the results indicated that male students' mean score $(\mathrm{M}=41.8, S D=7.1)$ was more than female students' mean score $(\mathrm{M}=$ $46.1, S D=10.4)$, with $\mathrm{t}(398)=-4.74, p<.001$ and eta squared of .053 implying a moderate difference effect. It was concluded that female students differed considerably from their male counterpart as they experienced more transitional challenges than males.

As it holds, the present study situates itself on undergraduate (bachelor of education) sandwich students who are pursuing their degree programmes under a University of Cape Coast, Ghana (public university). In Ghana, Ghana Education Service has pegged bachelor of education degree as the minimum requirement for the teaching profession at the basic level. So, it 
has become requirement for those in the teaching occupation to possess a minimum bachelors degree in education, hence diploma certificate students quest to upgrade themselves to meet the standard. As professional teachers, they are required to teach for some stipulated years (3-5 for urban teachers and 1-3 for rural teachers) before they could be given study leave with pay to upgrade themselves academically. Most often than not, these professional teachers are able to serve the required years and are due for study leave with pay, however, the perceived corrupt bureaucratic educational system in Ghana prevents genuine teachers who qualify to enjoy such opportunities. The situation gives room for these educational opportunities to be left in the hands of perceived few influential and privileged people in higher offices, who give the opportunities out to their favourites or allies or cronies.

Due to this, many of these teachers are compelled to enrol in seasonal educational programmes (sandwich) organized by the public universities, including a particular Public University, at every vacation so that those who could not get the opportunity to pursue their desired programmes through regular model could take advantage because schools would be on vacation and teachers might be free then. This practice has its own dynamics as those who get enrolled usually come from diverse towns and communities to converge at any of the designated satellite campuses to receive tuition and assessment. Coming from diverse backgrounds and cultures for a common purpose might pose a challenge to many of these students but it is undocumented to guide policy formulation, hence, the current study. In reviewing literature, many studies such as Muntazir and Kermane (2015), Enochs and Ronald (2006), Abdallah, Elias, Muhyddin, and Uli (2009) and Edjah, Domey, and Ankomah (2019) are conducted among students using the regular model or stream but little or no studies are found using undergraduate sandwich students, hence a gap in literature. Therefore, the researchers thought it imperative to dwell in this tangent using a certain College of Education Satellite Campus under a Public University as a focal point.

\section{Research Question}

1. What transitional challenges do undergraduate sandwich students encounter in school?

\section{Research Hypotheses}

1. $\mathbf{H}_{1}$ : There is gender difference in transitional challenges experienced by undergraduate sandwich students.

2. $\mathbf{H}_{\mathbf{1}}$ : There is programme difference in transitional challenges experienced by undergraduate sandwich students. 


\section{Methodology}

The study employed descriptive survey design with the quantitative approach. The design was appropriate for this study because it enabled the researchers examined situations descriptively and made no effort to determine cause and effect among the study respondents as may be the case in other quantitative designs. Using the descriptive survey design, situations and circumstances emanating from the study were described as they were and no manipulation of variables were considered. With the quantitative aspect, analysis and reporting was made in figures and numbers as a benchmark. Siding with Ethridge (2004), Ethridge (2004), Fox and Bayat (2007) and Fox and Bayat (2007) in the use of descriptive survey design, it clarified accounts of matters as they exist without the researcher having power over the variables under investigation. The objective of this design was about bring clarity to current issues and problems in sandwich education through a process of data collection that enabled the researchers to describe the situation possible and adequately. Advantageously, descriptive survey design research can provide an in-depth view of any phenomenon researchers might wish to investigate and the details provided in this phenomenon are exceedingly valuable. However, the choice of descriptive survey design offers researchers less opportunity to determine any causeand-effect relationship from their investigation (Sumeracki, 2018).

The population for the study was all undergraduate sandwich students in a certain College of Education satellite Campus with a population of 690 students. The population comprised students who were pursuing Bachelor of Education Home Economics Programme and Bachelor of Education Arts. The male and female student numbers were not equal in terms of gender and programmes of study.

The sample size for the study was 690 undergraduate sandwich students in a College of Education Satellite Campus as a reflection of the population. The sample size of 690 was used through census, where every student in the study area was deemed qualified to be part of the study. In this study, no stringent sampling criteria was established for the students but one could only take part if he or she had enrolled for undergraduate Home Economics or Arts Programme in the College of Education Satellite Campus.

The study used an adapted questionnaire that was developed by Sanagavarapu, Abraham and Taylor (2018). In the adaptation, few modifications were made on some dimensions and items so that they could be contextually and culturally appropriate for usage. This instrument was named Transition, Wellbeing, Help-seeking, and Adjustments Scale (TWHAS) for the data collection. The original scale had 38-items distributed among four (4) dimensions: personal, socio-emotional, and academic challenges associated with transition to university (14-items; $\alpha=.74)$; moods 
and coping relating to students' wellbeing (12-items; $\alpha=.87)$; sociodemographic and psychological barriers to seeking help (11-items; $\dot{\alpha}=.87$ ), and overall transitional adjustments to university (1-item). The adapted version had 34-items distributed among three (3) dimensions: personal, socio-emotional, and academic challenges associated with transition to university (12-items; $\alpha=.73$ ) with scoring such as very easy $=1$, easy $=2$, difficult $=3$ and very difficult $=4$; moods and coping relating to students' wellbeing (12-items; $\alpha=.77$ ) with scoring never $=1$, rarely $=2$, often $=3$ and all the time $=4$; and socio-demographic and psychological barriers to seeking help (10-items; $\alpha=.80)$ with scoring strongly disagree $=1$, disagree $=2$, agree $=3$ and strongly agree $=4$. The original four (4) dimension was ignored as such transitional adjustments were reflective in the three (3) chosen dimensions.

The data gathered with the adapted scale was analysed quantitatively using descriptive and inferential statistical tools. The specific descriptive statistical tool used for analysing the research question was frequencies and percentages. This was used because the researchers wanted to know the extent to which students are challenged as they transit from their various stations to a common converging point for academic work. The specific inferential statistical tool used for testing the hypotheses was Multivariate Analysis of Variance (MANOVA). This was used because the researchers sought to find out if differences existed among male and female students and their programmes of study, using a multi-dimensional continuous variable.

\section{Results and Discussion}

This analysis espoused demographic and main data that are presented descriptively and hypothetically. The analysis and interpretations of the data were carried out based on the results of the formulated questions and hypothesis. The analysis was based on the $94 \%$ return rate of data obtained from 651 out of 690 respondents sampled for the study.

\section{Demographic Characteristics of the Respondents}

The demographic information was about respondents' gender and programme of study. Frequencies and percentages were used to present the findings as depicted in Table 1: 
Table 1: Demographic Characteristics of the Respondents

\begin{tabular}{llll}
\hline Variable & & Frequency & Percent \\
\hline Gender & Male & 218 & 33.5 \\
& Female & 433 & 66.5 \\
& Total & $\mathbf{6 5 1}$ & $\mathbf{1 0 0 . 0}$ \\
Programme Home Economics Education & 145 & 22.3 \\
& Arts Education & 506 & 77.7 \\
& Total & $\mathbf{6 5 1}$ & $\mathbf{1 0 0 . 0}$ \\
\hline
\end{tabular}

Source: Field Data (2020)

Table 1 presents result about the demographic characteristics of the respondents. Table 1 had two demographic characteristics such as gender and course of study. On the gender, female respondents dominated the sample with $66.5 \%$ (433) while male respondents were $33.5 \%$ (218). On the issue of course of study, Arts Education students dominated the sample with 77.7\% (506) and Home Economic Education students had 22.3\% (145).

\section{Main Results}

This aspect of the study is about transitional challenges among students. The challenges were in three (3) dimensions namely: personal, socio-emotional, and academic challenges; moods and coping, and sociodemographic and psychological barriers. Table 2 presents the results:

\begin{tabular}{|c|c|c|c|c|}
\hline \multicolumn{5}{|c|}{ Subscale 1: Personal, Socio-Emotional, and Academic Challenges } \\
\hline \multirow{2}{*}{$\begin{array}{l}\text { Since starting at University of Cape Coast, how } \\
\text { easy or difficult was it for you to } \\
\text { Scoring }\end{array}$} & \multicolumn{2}{|c|}{ Easy } & \multicolumn{2}{|c|}{ Difficult } \\
\hline & Freq. & $\%$ & Freq. & $\%$ \\
\hline Balance family commitments with studies. & 270 & 41.4 & 381 & 59.6 \\
\hline Balance financial commitments with studies. & 174 & 26.7 & 477 & 73.3 \\
\hline Find time to exercise. & 142 & 22.6 & 509 & 77.4 \\
\hline Travel to the university. & 239 & 36.7 & 412 & 63.3 \\
\hline $\begin{array}{l}\text { Make friends with people from similar backgrounds } \\
\text { on campus. }\end{array}$ & 507 & 77.9 & 144 & 22.1 \\
\hline $\begin{array}{l}\text { Make friends with people from different } \\
\text { backgrounds on campus }\end{array}$ & 474 & 72.8 & 177 & 27.2 \\
\hline Meet up with friends outside the university. & 254 & 39.0 & 397 & 61.0 \\
\hline Participate in studies and discussions. & 507 & 77.9 & 144 & 22.1 \\
\hline Feel respected by peers and other staff. & 572 & 87.9 & 79 & 12.1 \\
\hline Understand my course requirements. & 420 & 64.5 & 231 & 33.5 \\
\hline Complete my assessments. & 361 & 55.5 & 290 & 44.5 \\
\hline $\begin{array}{l}\text { Subscale 2: Moods and Coping } \\
\text { Since starting at University of Cape Coast, how } \\
\text { often do you feel }\end{array}$ & Never & Rarely & Often & $\begin{array}{l}\text { All } \\
\text { times }\end{array}$ \\
\hline
\end{tabular}




\begin{tabular}{|c|c|c|c|c|}
\hline Scoring & Freq. $/ \%$ & Freq. $/ \%$ & Freq./\% & $\begin{array}{l}\text { Freq./ } \\
\%\end{array}$ \\
\hline Misunderstood by others. & $224 / 34.4$ & $294 / 45.2$ & $105 / 16.1$ & $28 / 4.3$ \\
\hline Unable to concentrate on anything. & $220 / 33.8$ & $293 / 45.0$ & $129 / 19.8$ & $9 / 1.4$ \\
\hline Nervous when talking to people. & $355 / 54.5$ & $206 / 31.6$ & $76 / 11.7$ & $14 / 2.2$ \\
\hline Everything is too difficult. & $174 / 26.7$ & $239 / 36.7$ & $170 / 26.1$ & $68 / 10.4$ \\
\hline Pressurised to succeed from family. & $227 / 34.9$ & $233 / 35.8$ & $130 / 20.0$ & $61 / 9.4$ \\
\hline Worried (e.g. about money, study, family). & $164 / 25.2$ & $175 / 26.9$ & $202 / 31.0$ & $\begin{array}{l}110 / 16 . \\
9\end{array}$ \\
\hline Unable to fit into university & $453 / 69.6$ & $134 / 20.6$ & $39 / 6.0$ & $25 / 3.8$ \\
\hline Not wanting to go to a tutorial or lecture & $456 / 70.0$ & $136 / 20.9$ & $40 / 6.1$ & $19 / 2.9$ \\
\hline Lonely & $357 / 54.8$ & $195 / 30.0$ & $68 / 10.4$ & $31 / 4.8$ \\
\hline Tired for no good reason & $342 / 52.5$ & $177 / 27.2$ & $98 / 15.1$ & $34 / 5.2$ \\
\hline Irritable/tempered & $412 / 63.3$ & $163 / 25.0$ & $58 / 8.9$ & $18 / 2.8$ \\
\hline Low self-respect/importance & $511 / 78.5$ & $81 / 12.4$ & $46 / 7.1$ & $13 / 2.0$ \\
\hline \multicolumn{5}{|c|}{ Subscale 3: Socio-Demographic and Psychological Barriers } \\
\hline \multicolumn{5}{|l|}{$\begin{array}{l}\text { If you did not seek help, tick the below that } \\
\text { applies to you }\end{array}$} \\
\hline Scoring & Freq. & $\%$ & Freq. & $\%$ \\
\hline I would be concerned about what others would say. & 488 & 75.0 & 163 & 25.0 \\
\hline I would feel ashamed of myself in school. & 555 & 85.3 & 96 & 14.7 \\
\hline I would be concerned that others would find out & 503 & 77.3 & 148 & 12.7 \\
\hline I would not trust the support staff in my school & 556 & 85.4 & 95 & 14.6 \\
\hline I would be afraid to seek support from my colleagues & 533 & 81.9 & 118 & 18.1 \\
\hline $\begin{array}{l}\text { I would be concerned I may not be able to explain } \\
\text { my problems }\end{array}$ & 493 & 75.7 & 158 & 14.3 \\
\hline I would be concerned about language barriers. & 461 & 70.8 & 190 & 29.2 \\
\hline $\begin{array}{l}\text { I would be concerned that colleagues may not respect } \\
\text { my faith in school. }\end{array}$ & 514 & 79.0 & 137 & 21.0 \\
\hline $\begin{array}{l}\text { I would be concerned that colleagues may not } \\
\text { understand my cultural background in school. }\end{array}$ & 495 & 76.0 & 156 & 24.0 \\
\hline $\begin{array}{l}\text { I would be concerned that my family member, or } \\
\text { friend, cannot accompany me to school. }\end{array}$ & 526 & 80.8 & 125 & 19.2 \\
\hline
\end{tabular}




\section{Table 2: Transitional Challenges Experienced by Respondents}

Field Data (2020)

It can be deduced from the findings that virtually all statements in Table 2 were confirmed as being challenges concerning students transiting from their homes to their academic environment. In terms of personal, socioemotional, and academic challenges, $59.6 \%$ of the respondents indicated that they found it difficult in balancing family commitments with studies while $77.4 \%$ indicated that they found it difficult to find time to exercise. It was revealed that $61.0 \%$ of the respondents indicated they found it difficult to meet up with friends outside the university while $73.3 \%$ of the respondents indicated that they found it difficult to balance financial commitments with studies. However, $55.5 \%$ of the respondents indicated that they found it easy to complete their assessments while $77.9 \%$ of the respondents indicated that they found it easy to participate in studies and discussions. More so, $77.9 \%$ of the respondents indicated that they found it easy to make friends with people from similar backgrounds on campus while $77.2 \%$ of the respondents indicated that they found it easy to make friends with people from different backgrounds on campus and have problems attending regular lectures. It can be observed from the results that students were challenged in some aspects but not in others. The findings of the current study corroborate with that of Oliver and Kettley (2010). In their study, it was revealed that time management, flexibility, managing relationships and budgeting were among the transitional challenges they encounter and these are in line with the specific transitional challenge dimension. These findings were corroborated by Oliver and Kettley (2010) that such challenges are not just felt by students because of the new settings they find themselves but because $21^{\text {st }}$ century universities pride high grades than acquiring knowledge, hence a burden on new entrants.

In terms of moods and coping challenges, $45.2 \%$ rarely experienced misunderstanding with others, $16.1 \%$ respondents often experienced misunderstanding with others and $4.3 \%$ of the respondents always experienced misunderstanding with others. Again, $45.0 \%$ of the respondents rarely experienced lack of concentration, $19.8 \%$ of the respondents often experienced lack of concentration and $1.4 \%$ of the respondents always experienced lack of concentration. Furthermore, 36.7\% of the respondents rarely had trouble in everything, $26.1 \%$ of the respondents' oftenexperienced difficulty in everything and $10.4 \%$ of the respondents always had trouble in everything. In addition, $26.9 \%$ of the respondents rarely experienced worry about their family, money and studies, $31.0 \%$ of the respondents often experienced worry about their family, money and studies while $16.9 \%$ of the respondents always experienced worry about their family, money and studies. It is evident that indeed, students experienced 
some form of mood and coping challenges as they moved away from their comfort zones in terms of their homes to the new campus. The revelation of the current study debunks the assertion made by Wangeri, Kimani and Mutweleli (2012) that beginning university globally presents students with opportunities in diverse ways to define and advance their professional prospects but confirmed in part that many new university students hold mysterious fears and expectations about life and education in their academic journey (Wangeri, Kimani \& Mutweleli, 2012). Again, the findings support Hughes (2016), Kahneman (2012) and Tinto's (2013) submissions that several students are faced with unclear or impractical expectations of university as beginners.

In terms of socio-demographic and psychological barriers, $25.0 \%$ of the respondents agreed that they were always concerned about what others would say about them while $29.2 \%$ of the respondents agreed that they were concerned about language barrier in the new tertiary environment. Again, $24.0 \%$ of the respondents agreed that many of their colleagues might not understand their cultural backgrounds in school while $21.0 \%$ of the respondents agreed that they would be concerned about colleagues not respecting their faith in school. However, $85.3 \%$ of the respondents disagreed that they might feel ashamed of themselves in school while $85.4 \%$ of the respondents disagreed that they would not trust the support of staff in their school as they pursue higher education. In addition, $81.9 \%$ of the respondents disagreed that they would be afraid to seek support from their colleagues while $75.7 \%$ of the respondents agreed that they would be concerned about not being able to explain their problems to others in school. Per the findings, only few students might be challenged sociodemographically and psychologically. This could be as a result that these students have ever been to tertiary school during their diploma training, hence their ability to withstand such situations because they might be experienced similarly. The revelation of the current study disconfirms the assertion made by Norton, Keenan, Williams, Elander and McDonough (2009) that many students start university without the required personal, social and academic skills for a successful integration into the University because these category of students have ever attended tertiary institutions to acquire their diploma certificates that mandate them to teach in Ghanaian basic schools, hence, their flexibility in the areas of socio-demographic and psychological barriers in the transitional process.

\section{Research Hypothesis One}

One of the objectives of the study was to determine the differences in gender with respect to the transitional challenges (personal, socio-emotional, and academic; moods and coping; socio-demographic and psychological 
barriers) faced by undergraduate sandwich students in a certain College of Education. The challenges were in three categories and as such MANOVA was appropriate for the analysis and the dependent variable had more than one level against gender (male and female). Table 3 presents the results on the descriptive statistics:

Table 3: Descriptive Statistics

\begin{tabular}{|c|c|c|c|c|}
\hline \multirow{2}{*}{$\begin{array}{l}\text { Demographic } \\
\text { Personal, Socio-emotional and Academic Challenges }\end{array}$} & \multirow[b]{2}{*}{ Male } & \multirow{2}{*}{$\begin{array}{l}\text { M } \\
26.47\end{array}$} & \multirow{2}{*}{$\frac{\text { SD }}{4.43}$} & \multirow{2}{*}{$\begin{array}{l}\mathbf{N} \\
218\end{array}$} \\
\hline & & & & \\
\hline & Female & 27.12 & 5.25 & 433 \\
\hline & Total & 26.90 & 5.00 & 651 \\
\hline \multirow[t]{3}{*}{ Moods and Coping Challenges } & Male & 21.84 & 5.39 & 218 \\
\hline & Female & 20.75 & 5.30 & 433 \\
\hline & Total & 21.12 & 5.35 & 651 \\
\hline \multirow[t]{3}{*}{ Socio-demographic and Psychological barriers } & Male & 18.92 & 5.57 & 218 \\
\hline & Female & 18.34 & 5.46 & 433 \\
\hline & Total & 18.53 & $\mathbf{5 . 5 0}$ & 651 \\
\hline
\end{tabular}

Source: Field Data (2020)

Table 3 showed that descriptive results of the study variables that indicated that there were differences in the mean scores of the gender of respondents based on their transitional challenges. For instance, male students had less personal, socio-emotional and academic challenges $(\mathrm{M}=26.47, \mathrm{SD}=4.43)$, than female students $(\mathrm{M}=27.12, \mathrm{SD}=5.25)$. In terms of mood and coping challenges, female students experienced them $(M=20.75$, $\mathrm{SD}=5.30)$ more than male students $(\mathrm{M}=21.84, \mathrm{SD}=5.39)$. Again, female students experienced socio-demographic, and psychological barriers are $(\mathrm{M}=18.34, \mathrm{SD}=5.46)$ less than male students $(\mathrm{M}=18.92, \mathrm{SD}=5.57)$. There were differences observed descriptively, but then, these might not be statistically significant so there was the need for further examination using the Multivariate Test from the MANOVA analysis. Table 4 presents the results:

Table 4: Multivariate Test

\begin{tabular}{|c|c|c|c|c|c|c|c|}
\hline \multicolumn{2}{|l|}{ Effect } & \multirow{2}{*}{$\begin{array}{l}\text { Value } \\
.970\end{array}$} & \multirow{2}{*}{$\begin{array}{l}\mathbf{F} \\
6950.117^{\mathrm{b}}\end{array}$} & \multirow{2}{*}{\begin{tabular}{|l}
$\begin{array}{l}\text { Hypot } \\
\text { hesis } \\
\text { df }\end{array}$ \\
3.000
\end{tabular}} & \multirow{2}{*}{$\begin{array}{l}\text { Error df } \\
647.000\end{array}$} & \multirow{2}{*}{$\begin{array}{l}\text { Sig. } \\
.000\end{array}$} & \multirow{2}{*}{$\begin{array}{l}\begin{array}{l}\text { Partial } \\
\text { Eta } \\
\text { Squared }\end{array} \\
.970\end{array}$} \\
\hline \multirow{4}{*}{ Intercept } & Pillai's Trace & & & & & & \\
\hline & Wilks' Lambda & 030 & $6950117^{\mathrm{b}}$ & 3000 & 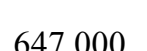 & 000 & 970 \\
\hline & Hotelling's Trace & 322 & $6950117^{\mathrm{b}}$ & 3000 & 647000 & 000 & 970 \\
\hline & Roy's Largest Root & 32.226 & $6950.117^{\mathrm{b}}$ & 3.000 & 647.000 & .000 & .970 \\
\hline Gender & Pillai's Trace & .021 & $4.573^{\mathrm{b}}$ & 3.000 & 647.000 & .004 & .021 \\
\hline
\end{tabular}




\begin{tabular}{lllllll}
\hline Wilks' Lambda & .979 & $4.573^{\mathrm{b}}$ & 3.000 & 647.000 & .004 & .021 \\
Hotelling's Trace & .021 & $4.573^{\mathrm{b}}$ & 3.000 & 647.000 & .004 & .021 \\
Roy's Largest Root & .021 & $4.573^{\mathrm{b}}$ & 3.000 & 647.000 & .004 & .021 \\
\hline
\end{tabular}

\section{Source: Field Data}

Table 4 presents the results of the multivariate tests (MAVOVA) which checked for statistical differences between male and female students in terms of their transitional challenges. In examining the Table 4, the Wilks' Lambda results showed statistically significant differences in gender of the students with respect to transitional challenges (personal, socio-emotional, and academic; moods and coping; socio-demographic and psychological barriers) $F(3,647)=4.57, \mathrm{p}=.004$ Wilks' Lambda $=.98$, partial eta squared $=$ .021. Based on the statistically significant difference detected, there was the need to find out which dependent variable contributed to that difference using the Tests of Between-Subjects Effects. Table 4 presents the results:

Table 5: Test of Between-Subjects Effect

\begin{tabular}{|c|c|c|c|c|c|c|c|c|}
\hline Source & Dependent $\mathrm{Va}$ & riable & $\begin{array}{l}\text { Type III Sum } \\
\text { of Squares }\end{array}$ & $\mathrm{df}$ & $\begin{array}{l}\text { Mean } \\
\text { Square }\end{array}$ & $\mathrm{F}$ & Sig. & $\begin{array}{l}\text { Partial } \\
\text { Eta } \\
\text { Square } \\
\text { d }\end{array}$ \\
\hline \multirow[t]{3}{*}{ Corrected Model } & $\begin{array}{l}\text { Personal, } \\
\text { emotional } \\
\text { Academic } \\
\text { Challenges }\end{array}$ & $\begin{array}{l}\text { Socio- } \\
\text { and }\end{array}$ & 62.554 & 1 & 62.554 & 2.51 & $\begin{array}{l}.11 \\
4\end{array}$ & .004 \\
\hline & $\begin{array}{l}\text { Moods } \\
\text { Coping } \\
\text { Challenges }\end{array}$ & and & 171.916 & 1 & 171.916 & 6.05 & $\begin{array}{l}.01 \\
4\end{array}$ & .009 \\
\hline & $\begin{array}{l}\text { Socio-demog } \\
\text { and Psych } \\
\text { barriers }\end{array}$ & $\begin{array}{l}\text { graphic } \\
\text { lological }\end{array}$ & 48.819 & 1 & 48.819 & 1.62 & $\begin{array}{l}.20 \\
4\end{array}$ & .002 \\
\hline \multirow[t]{3}{*}{ Intercept } & $\begin{array}{l}\text { Personal, } \\
\text { emotional } \\
\text { Academic } \\
\text { Challenges }\end{array}$ & $\begin{array}{r}\text { Socio- } \\
\text { and }\end{array}$ & 416459.789 & 1 & 416459.79 & 16711.39 & $\begin{array}{l}.00 \\
0\end{array}$ & .963 \\
\hline & $\begin{array}{l}\text { Moods and } \\
\text { Challenges }\end{array}$ & Coping & 263014.221 & 1 & 263014.22 & 9256.62 & $\begin{array}{l}.00 \\
0\end{array}$ & .934 \\
\hline & $\begin{array}{l}\text { Socio-demog } \\
\text { and Psych } \\
\text { barriers }\end{array}$ & $\begin{array}{l}\text { graphic } \\
\text { lological }\end{array}$ & 201244.272 & 1 & 201244.27 & 6660.49 & $\begin{array}{l}.00 \\
0\end{array}$ & .911 \\
\hline \multirow[t]{3}{*}{ Gender } & $\begin{array}{l}\text { Personal, } \\
\text { emotional } \\
\text { Academic } \\
\text { Challenges }\end{array}$ & $\begin{array}{r}\text { Socio- } \\
\text { and }\end{array}$ & 62.554 & 1 & 62.554 & 2.51 & $\begin{array}{l}.11 \\
4\end{array}$ & .004 \\
\hline & $\begin{array}{l}\text { Moods and } \\
\text { Challenges }\end{array}$ & Coping & 171.916 & 1 & 171.916 & 6.05 & $\begin{array}{l}.01 \\
4\end{array}$ & .009 \\
\hline & $\begin{array}{l}\text { Socio-demog } \\
\text { and Psych } \\
\text { barriers }\end{array}$ & $\begin{array}{l}\text { graphic } \\
\text { lological }\end{array}$ & 48.819 & 1 & 48.819 & 1.62 & $\begin{array}{l}.20 \\
4\end{array}$ & .002 \\
\hline
\end{tabular}




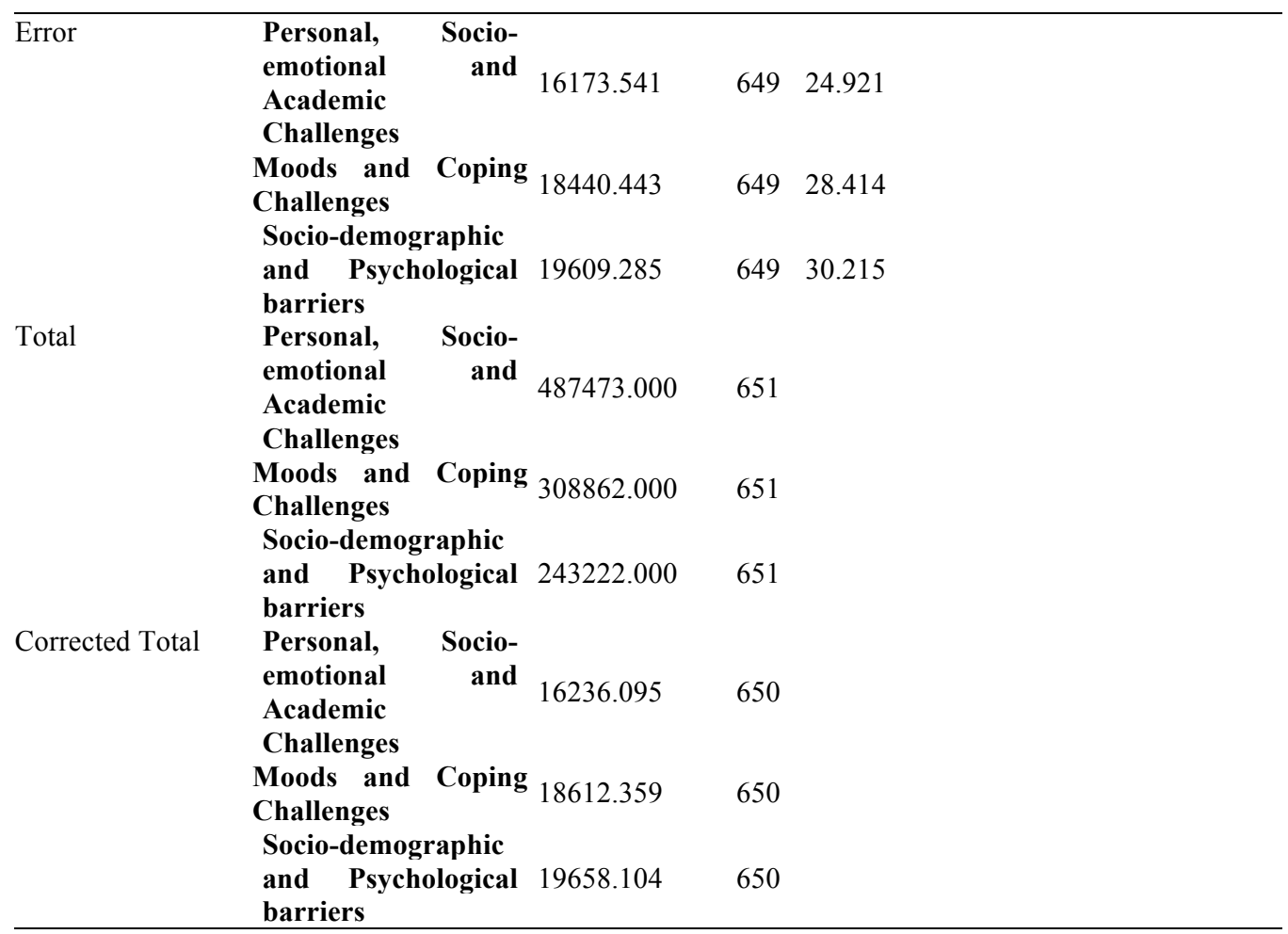

Source: Field Data

Table 5 showed the results for the Tests of Between-Subjects Effects to substantiate the differences observed in the multivariate analysis. Before going further to report, it was important to follow protocols purposely to avoid Type I statistical error (establishing a difference where indeed, there was none). In controlling for Type I Error, Bonferroni simple formular $(.05 / 3=.0167)$ was considered to arrive at a new alpha level of .0167 purposely for establishing a true difference (Tabachnick \& Fidell, 2013, p. 272). After which, the results for the dependent variables were separately considered using the new alpha level of .0167. Careful examination showed statistical difference existed only in mood and coping challenges of students, $F(1,649)=6.05, \mathrm{p}=.014$, partial eta squared $=.009$. Concerning the effect sizes established, mood and coping challenges were small based on Cohen (1988, p. 284-287).

Inspection of the mean scores revealed that male sandwich students in a certain College of Education experience mood and coping challenges than their female counterparts in terms of transitional challenges. In this regard, the null hypothesis is rejected in favour of the alternate hypothesis. The findings of the current study debunked a contrary study conducted in Ghana by Edjah, Domey, and Ankomah (2019). Their study revealed, among others, that male first year university students experienced less transitional 
challenges than their female counterpart. Conversely, Surekha's (2008) study findings contradict the revelation of the current study revelation that female transiting students experience more transitional problems than their male colleagues. However, Muntazir and Kermane's (2015) study findings neither supports or opposes the current study revelation as no differences were recorded between male and female in transitional problems among transiting university students. Therefore, gender could not contribute to any challenge transiting student experienced in the university (Muntazir \& Kermane, 2015). Thus, it is not convincing to state that a particular gender suffers the most than the other among first year university students, hence, no superiority could be assigned because transitional situations could be diverse based on context and geographical settings.

\section{Research Hypothesis Two}

The study investigated differences in transitional challenges based on programmes read by students. In this case, the independent variables were Home Economics Education and Arts Education while dependent variables were personal, socio-emotional, and academic; moods and coping; sociodemographic and psychological barriers. Based on the nature of the variables, differences could only be conducted using MANOVA after assumptions were satisfied. Table 6 presents the descriptive statistics of the multivariate analysis:

Table 6: Descriptive Statistics based on Programmes

\begin{tabular}{|c|c|c|c|c|}
\hline \multirow{2}{*}{$\begin{array}{l}\text { Subscales } \\
\text { Personal, Socio-emotional and } \\
\text { Academic Challenges }\end{array}$} & Programme & $\mathbf{M}$ & SD & $\mathbf{N}$ \\
\hline & $\begin{array}{l}\text { Home } \\
\text { Economics }\end{array}$ & 27.01 & 4.64 & 145 \\
\hline \multirow[b]{3}{*}{ Moods and Coping Challenges } & $\begin{array}{l}\text { Arts } \\
\text { Education }\end{array}$ & 26.88 & 5.10 & 506 \\
\hline & Total & 26.90 & 5.00 & 651 \\
\hline & $\begin{array}{l}\text { Home } \\
\text { Economics }\end{array}$ & 20.90 & 5.68 & 145 \\
\hline \multirow{5}{*}{$\begin{array}{l}\text { Socio-demographic } \\
\text { Psychological barriers }\end{array}$} & $\begin{array}{l}\text { Arts } \\
\text { Education }\end{array}$ & 21.18 & 5.26 & 506 \\
\hline & Total & 21.12 & 5.35 & 651 \\
\hline & $\begin{array}{l}\text { Home } \\
\text { Economics }\end{array}$ & 18.82 & 6.06 & 145 \\
\hline & $\begin{array}{l}\text { Arts } \\
\text { Education }\end{array}$ & 18.45 & 5.33 & 506 \\
\hline & Total & 18.53 & 5.50 & 651 \\
\hline
\end{tabular}

Source: Field Data 
Table 6 showed that descriptive results of the variables indicating that differences existed in the mean scores of the programme of respondents against transitional challenges (personal, socio-emotional, and academic; moods and coping; socio-demographic and psychological barriers). For instance, students pursuing home economics $(\mathrm{M}=27.01, \quad \mathrm{SD}=4.64)$ experienced personal, socio-emotional, and academic challenges students pursuing arts education $(\mathrm{M}=26.88, \mathrm{SD}=5.10)$. In terms of mood and coping challenges, students pursuing arts education $(\mathrm{M}=21.18, \quad \mathrm{SD}=5.26)$ experienced them than students pursuing home economics (Mean=20.90, $\mathrm{SD}=5.68)$. Furthermore, students pursuing home economics (Mean=18.82, $\mathrm{SD}=6.06)$ experienced socio-demographic and psychological barriers than students pursuing arts education (Mean=18.53, $\mathrm{SD}=5.50$ ). There were differences observed descriptively, but then, these might not be statistically significant so there was the need for further examination using the Multivariate Test from the MANOVA analysis. Table 7 presents the results:

\section{Table 7: Multivariate Tests based on Programmes}

\begin{tabular}{|c|c|c|c|c|c|c|c|}
\hline Effect & & Value & $\mathbf{F}$ & $\begin{array}{l}\text { Hypothe } \\
\text { sis df }\end{array}$ & Error df & Sig. & $\begin{array}{l}\text { Partial Eta } \\
\text { Squared }\end{array}$ \\
\hline \multirow[t]{4}{*}{ Intercept } & Pillai's Trace & .962 & 5415.735 & 3.000 & 647.000 & .000 & .962 \\
\hline & Wilks' Lambda & .038 & 5415.735 & 3.000 & 647.000 & .000 & .962 \\
\hline & $\begin{array}{l}\text { Hotelling's } \\
\text { Trace }\end{array}$ & 25.112 & 5415.735 & 3.000 & 647.000 & .000 & .962 \\
\hline & $\begin{array}{l}\text { Roy's Largest } \\
\text { Root }\end{array}$ & 25.112 & 5415.735 & 3.000 & 647.000 & .000 & .962 \\
\hline \multirow[t]{4}{*}{ Programme } & Pillai’s Trace & .002 & .470 & 3.000 & 647.000 & .704 & .002 \\
\hline & Wilks' Lambda & .998 & .470 & 3.000 & 647.000 & .704 & .002 \\
\hline & $\begin{array}{l}\text { Hotelling's } \\
\text { Trace }\end{array}$ & .002 & .470 & 3.000 & 647.000 & .704 & .002 \\
\hline & $\begin{array}{l}\text { Roy's Largest } \\
\text { Root }\end{array}$ & .002 & .470 & 3.000 & 647.000 & .704 & .002 \\
\hline
\end{tabular}

Source: Field Data (2020)

Table 7 presents the results of the multivariate tests (MAVOVA) that indicated statistical differences between home economics students and arts education students concerning their transitional challenges. In examining the Table 7, the Wilks' Lambda results showed no significant difference existed in students' programmes of study in terms of transitional challenges. Thus, $F(3,647)=.470$, $\mathrm{p}=.704$; Wilks' Lambda $=1.00$, partial eta squared $=.002$. Based on the no significant difference detected, there was no need to study the Tests of BetweenSubjects Effects but to conclude based on the fact that no differences existed in students' transitional challenges by comparing the progammes they pursue. Therefore, the null hypothesis was not rejected. The findings indicate that irrespective of the programme a student pursues, it has no role in determining the transitional challenges one may face at the beginning to the end of the programme. Presumably, it is clear that transitional challenges experienced by new university 
students do not consider the programmes pursued by students and challenges faced by such students are not measured in terms of the kind of academic programme they enrol to pursue. Hence, no authority expatiates the fact that students starting university may differ in their transitional challenges in terms of their academic programme choice.

\section{Conclusions}

Once education cannot be discarded from humanity, its consequences are bound to be felt. The researchers conclude that students who pursue academic programmes through the sandwich streams are faced with transitional challenges just like their counterparts who pursue their academic programmes through regular stream but just challenges might be severe as most academic works are compacted for a very short time unlike those in regular. Such transitional challenges have no regard for gender as both could be affected but males could be challenged more than their female counterparts. However, transitional challenges could not be attributed to the kind of academic programme a student enrols to pursue.

\section{Recommendations}

Based on the conclusion, it is recommended that managers and planners of such sandwich academic programmes put remedial measures in place to control the rippling effect of transitional challenges students may encounter as they enrol to pursue their desired academic programmes. Such remedial programmes could be constant guidance and counselling programmes offered for troubled students, organisation of fora for students bring forth what could hinder their successful integration and above all, going virtual for students to pursue such programmes in the comfort of their homes without necessarily travelling from far distances to any of the satellite campuses.

\section{References:}

Abdallah, M. C., Elias, H., Muhyddin, R., \& Uli, J. (2009). Adjustment among First Year Students in a Malaysian University. European Journal of Social Science, 5(3), 47-56.

Bernier, A., Larose, S., \& Whipple, N. (2005). Leaving home for college: A potentially stressful event for adolescents with preoccupied attachment patterns. Attachment and Human Development, 7(2), 171185.

Edjah, K., Domey, E., \& Ankomah, F. (2019). Experiences of level 100 undergraduate students in developing countries: A case study in University of Cape Coast, Ghana. International Journal of Social Sciences \& Educational Studies, 5(4), 1-10. 
Enochs, W. C., \& Roland, C. B. (2006). Social adjustment of college freshmen: the importance of gender and living environment. College Student Journal, 4(2), 32-41.

Ethridge, D. E. (2004). Research methodology in applied economics. John Wiley \& Sons.

Fox, W. \& Bayat, M. S. (2007). A guide to managing research. Juta Publications.

Harvey, L., Drew, S., \& Smith, M. (2006). The first-year experience: a review of literature for the higher education academy. Retrieved from

www.heacademy.ac.uk/sites/default/files/first_year_experience_full report.pdf.

Hughes, G. (2016). Transition distress: A psychological process. University and College Counselling, 4(3).

Jeyagowri, K. \& Ilankumaran, M. (2018). The role of students in transition from school to college: Different challenges in ELT. International Journal of Engineering and Technology, 7(4), 630-635.

Kahneman, D. (2012). Thinking, fast and slow. London: Penguin Books.

Muntazir, N. \& Kermane, M. (2015). Adjustment problems of college students in relation to gender, socioeconomic status and academic achievement. International Journal of Current Research, 7(4), 14574-14578.

Norton, L., Keenan, P., Williams, K., Elander, J., \& McDonough, G. (2009). Helping students make the transition from A-level to degree level writing: a staged action research approach. BERA Annual Conference, Manchester.

Oliver, C., \& Kettley, N. (2010). Gatekeepers or facilitators: The influence of teacher habitus on students' applications to elite universities. British Journal of Sociology of Education, 31(6), 737-753.

Parker, H., Hughes, A., Marsh, C., Ahmed, S., Cannon, J., Taylor-Steeds, E., Jones, L., \& Page, N. (2017). Understanding the different challenges facing students in transitioning to university particularly with a focus on ethnicity. New Directions in the Teaching of Physical Sciences, 12(1), 1-11.

Perry, C., \& Allard, A. (2003). Making the connections: Transition experience for first-year education students. Journal of Educational Enquiry, 4(2), 74-89.

Sanagavarapu, P., Abraham, J., \& Taylor, E. (2018). Development and validation of a scale to measure first year students' transitional challenges, wellbeing, help-seeking, and adjustments in an Australian University. High Education, 1-20. https://doi.org/10.1007/s 10734018-0298-2. 
Sangeeta, C. (2012). A study of adjustment problems of college students in relation to gender, socio-economic status and academic achievement. International Journal of Social \& Movement Sciences, 1(2), 14-25.

Sukrekha, D. (2008). Relationship between Studies adjustment and academic achievement. Educational Track, 7(7), 26-31.

Sumeracki, M. (2018). Different research methods: Strengths and weaknesses. Retrieved from https://www.learningscientists.org/blog/2018/3/8-1 on 30/04/2020.

Tabachnick, B. G., \& Fidell, L. S. (2013). Using multivariate statistics. International Edition: Pearson, California.

Tinto, V. (2013). Enhancing student success: Lessons learned. Presentation at 16th International First Year Experience Conference, Wellington.

Walker, L. (2010). Longitudinal study of drop-out and continuing students who attended the pre-university summer school at the University of Glasgow. International Journal of Lifelong Education, 13(3), 217233.

Wangeri, T., Kimani, E. \& Mutweleli, S. M. (2012). Transitional challenges facing university first year students in Kenyan Public Universities: A case of Kenyatta University. Interdisciplinary Review of Economics and Management, 2(1), 41-52.

Zajonc, R. (2001). Mere exposure: A gateway to the subliminal. Current Directions in Psychological Science, 10(6), 224-228. 